African Crop Science Journal by African Crop Science Society is licensed under a Creative Commons Attribution 3.0 Uganda License. Based on a work at www.ajol.info/ and www.bioline.org.br/cs DOI: http://dx.doi.org/10.4314/acsj.v26i3.7

\title{
ANALYSIS OF CITRUS VALUE CHAIN IN EASTERN UGANDA
}

\author{
H. KONGAI, J. MANGISONI, G. ELEPU' ${ }^{1}$, E. CHILEMBWE and D. MAKOKA \\ Bunda College of Agriculture, Lilongwe University of Agriculture and Natural Resources, P. O. Box 219, \\ Bunda, Lilongwe, Malawi \\ ${ }^{1}$ College of Agricultural and Environmental Sciences, Makerere University, P. O. Box 7062, Kampala, Uganda \\ Corresponding author: hellenbiruma@yahoo.com
}

(Received 19 March, 2018; accepted 10 August, 2018)

\begin{abstract}
Citrus farming is a smallholder enterprise in Eastern Uganda that has been prioritised and has received significant strategic support from government. However, farmers are variably engaging and benefiting from it probably due to existing inefficiencies in the value chain. This study aimed at analysing the citrus value chain, to identify factors affecting its performance, to foster citrus market competitiveness. The study involved citrus farming households, input suppliers, processors and traders. Cross sectional data were obtained and analysed using value chain mapping and gross margin analysis techniques. Results showed that farmers produce citrus using traditional technologies, including use of informally distributed planting materials with limited chemicals and irrigation. Value addition is limited and processing is still a critical missing link, thus fruits are commonly sold fresh. Generally, the value chain is not well coordinated and there is lack of trust among actors. Nevertheless, gross margin analysis shows that citrus farming is a profitable venture, which can lead to improvement in smallholder farm incomes and gainful employment in some segments of the value chain. Thus, citrus value chain upgrading opportunities lie within provision of quality planting materials, processing for value addition, and establishment of commodity innovation platforms.
\end{abstract}

Key Words: Actors, margins, oranges, smallholder

\section{RÉSUMÉ}

La production des agrumes est une entreprise de petits exploitants à l'Est d'Ouganda qui a été prioritisée et a reçu de soutien stratégique de la part du Gouvernement. Néanmoins, les producteurs sont variablement engagés et en bénéficient probablement du fait de l'inefficacité de la chaîne de valeur. Cette étude a pour objectif d'analyser la valeur de chaîne de l'agrume pour identifier les facteurs affectant sa performance pour accroitre la compétitivité du marché des agrumes. Cette étude a impliqué les exploitants agricoles, les fournisseurs d'intrants, les transformateurs et les commerçants. Les données transversales ont été obtenues et analysées en utilisant la schématisation de la chaîne de valeur et les techniques d'analyse des marges brutes. Les résultats ont montré que les exploitants produisent les agrumes en utilisant les technologies traditionnelles, y compris l'usage des matériels de plantation traditionnellement distribués avec un usage limité des produits chimiques et d'irrigation. La valeur ajoutée est limitée et la transformation demeure un maillon critique manquant, donc les fruits sont couramment vendus frais. Généralement, la chaîne de valeur n'est pas bien coordonnée et il y a un manque de confiance parmi les acteurs. Néanmoins, les résultats de l'analyse des marges brutes montrent que la production des agrumes est une opération rentable, qui peut conduire à l'amélioration des revenus des petits producteurs et un emploi rémunérateur dans certains segments de la chaîne de valeur. Par conséquent, la chaîne de valeur des agrumes donne 
lieu à des possibilités de perfectionnement dans la fourniture des matériels de plantation de qualité, la transformation pour de la valeur ajoutée, et la mise en place des plateformes d'innovation de la commodité.

Mots Clés: Acteurs, marges, oranges, petit exploitant

\section{INTRODUCTION}

Commercial production of citrus in Uganda started as early as the 1960 s, with the introduction of various improved varieties planted on Government schemes at Kiige, Ongino, Odina and Labori in eastern Uganda (Uganda Investment Authority, 2009). For over a decade, the schemes operated successfully, supplying fresh fruits to domestic and regional markets, till they declined due to ineffective management, caused by insurgency. Commercial production of citrus only began picking up again in the 1990s, but under the smallholder system and for the past two decades, citrus has received strategic development and promotional support, first through the National Agricultural Advisory Services (NAADS), and now through Operation Wealth Creation and some nongovernment organisations (NGOs). Through this support, farmers were trained in the use of budding and grafting technologies. Use and adoption of these technologies led to increased output (PMA, 2009; UDC, 2012); for instance, output for Teso subregion alone rose from 200,000 tonnes contributing 67 billion Uganda shillings (US\$ 30 million) to 360,000 tonnes, with an annual contribution of about 111 billion Uganda shillings (equivalent to US\$ 47 million) to agricultural Gross Domestic Product (PMA, 2009). However, farmers have not yet fully realised the benefits of commercialised production due to, among other constraints, limited market (PMA, 2009; Kongai et al., 2011).

Citrus market challenges have been partly attributed to the sub-optimal performance of the value chain (Kongai et al., 2017). Generally, the citrus value chain is predominated by small scale producers and traders, with weak linkages to markets. Trade transactions are mainly cash on-the spot, yet quality and value enhancement is limited (Kongai et al., 2011).

In a globalised economy, agricultural producer markets competitiveness is determined by efficient and effective organisation of internal processes, structures, resources and appropriate positioning as part of a chain linking production to consumers (Porter, 1985; Collins, 2011). For that reason, information pertinent to the commodity's value chain is critical for proper understanding of activities and linkages between upstream and downstream actors to guide design of mechanisms for leveraging improved value chain performance (Tchale and Keyser, 2010). This study aimed at analysing the citrus value chain in Teso sub region in eastern Uganda, so as to identify key challenges and opportunities in the production, processing and marketing of oranges crop.

\section{METHODOLOGY}

Study area. The study was carried out in Kaberemaido, Kumi and Soroti districts in Kyoga Plains Agricultural Zone in Uganda, during 2011. Kyoga Plains Agricultural Zone was chosen mainly because it is the main citrus producing zone in Uganda. Also, under National Agricultural Advisory Services (NAADS), citrus was chosen as one of Kyoga Plains Agricultural Zone's priority strategic commercial enterprises. Soroti, Kumi and Kaberemaido districts are located in Teso subregion, which devoted over 700 hectares of land to citrus, producing over 200,000 tonnes and contributing about 67 billion Uganda shillings (US\$ 28,389,830.5) to smallholder income in the region (PMA, 2009). This output level was expected to reach 360,000 tonnes with an annual contribution of about 111 billion 
Shillings to agriculture income by 2011. In 2015 , the output level was estimated at 769,177 tonnes (UDC, 2015a).

Study sample and data collection. To ensure inclusion of individuals or groups that were knowledgeable and had experience relevant to citrus farming and marketing, a multi-stage sampling criteria was used. Four sub-counties per district were randomly selected resulting into involvement of 12 sub-counties in the study. Citrus farming household were selected using random and respondent driven sampling (RDS) criteria. Respondent driven sampling improved the snowball sampling approach to minimise bias in sampling hard-to-reach populations (Johnston and Sabin, 2010). So, RDS was aimed at facilitating selection of citrus farmers with knowledge and experience in citrus farming as a business; and random sampling was used to ensure inclusion of respondents from each of the target subcounties and more remote parts of the subcounties. The process involved randomly selecting the initial respondent at each subcounty. Once the initial households were identified, face to face interviews were administered to a household member preferably the head. After the interview, the respondent was asked to provide an unlimited number of citrus farming households. The list obtained from the respondent was then used to randomly select the next respondent who also was taken through a similar process. The process was repeated several times within each sub-county and throughout the 3 districts, until the target sample of 392 households was reached.

For other value chain actors (input suppliers, output traders, marketeers and processors), the samples were drawn from those named or identified along the chain; and followed up for interview as key informants. Overall, we collected data covering 2009 and 2010 farming periods, using structured questionnaires for input suppliers, household heads, processors and traders and interview guides for key informants.

Analytical framework. Given its advantages and suitability, the value chain mapping technique was used for functional and technical analysis of the citrus value chain. A horizontal value chain map was used to depict upstream activities and functions, including input supply, farm production and downstream activities such as wholesaling and retailing of the produce (Fig. 1). This was aimed at depicting key qualitative information to direct or redirect the focus of stakeholders for enhanced market competitiveness. However, value chain mapping was limited in that it could not be used for quantitative value chain analysis.

The gross margin analytical technique was used to perform financial analysis of the citrus value chain because of its suitability for quantitative analysis. This involved computing and comparing various actors' gross margins. In the computation of gross margin shares from production to distribution, annual orange consumer price index (CPI, 2009) was used as a base because it was a better representative of the general consumer price and facilitated comparison (UBOS, 2009). Using data from the Uganda Bureau of Statistics (2009), the annual CPI was computed as an average of the monthly CPIs based on locations.

Overall, the citrus marketing channels were categorised into city and other channels. Accordingly, two channels' gross margins were computed. The city channel covered distribution of oranges from smallholders, through various traders, to city consumers; while other channel involved distribution of oranges from smallholders through traders to various towns and local consumers. To compute city channel gross margins, average city wholesale and retail prices were each divided by the city index. Other channel gross margins were computed using average wholesale and retail prices for respective 


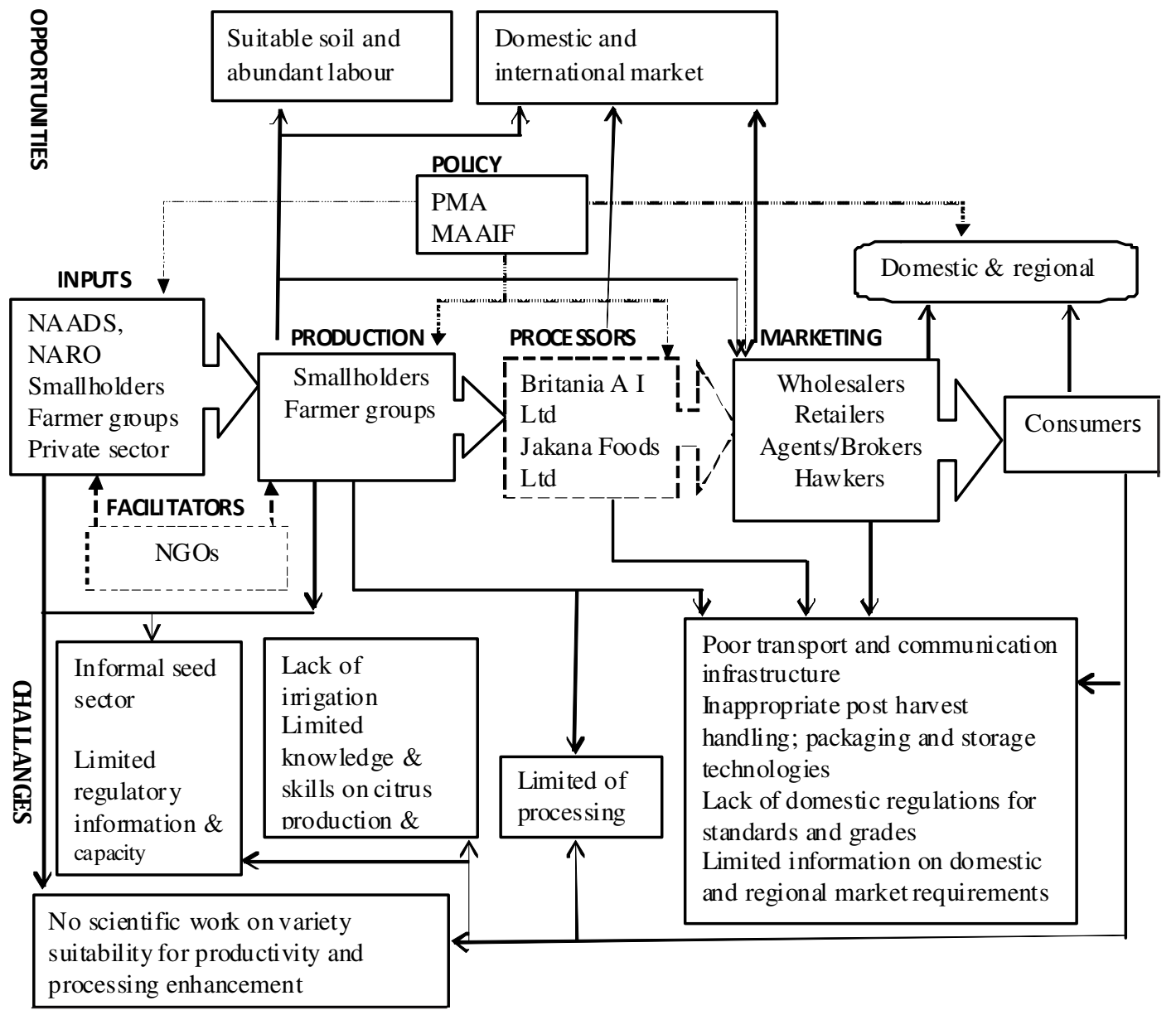

Figure 1. Kyoga Plains Agricultural Zone citrus value chain map depicting opportunities and challenges.

locations divided by the respective average CPI.

\section{RESULTS AND DISCUSSION}

Citrus value chain map. Value chain mapping results showed actors to comprised of Government agencies, farmers and private sector (Fig. 1). Government agencies included Plan for Modernisation of Agriculture (PMA), National Agricultural Advisory Services (NAADS), National Agricultural Research Organisation (NARO) and the Ministry of Agriculture Animal Industry and Fisheries (MAAIF). NARO acted through the National Agricultural Resources Research
Institute (NaCRRI), the National Agricultural Research Laboratories (NALR) and the National Semi Arid Agricultural Research Institute (NaSAARI). MAAIF supervised production of quality seeds and distribution of agricultural inputs thus contributing to enforcement of agricultural policies.

NARO through its agencies managed citrus mother gardens, distributed clean planting material for seed multiplication and provided extension through its demo orchards located at the research stations for good practice teaching and learning. The private sector actors mainly included Soroti Agricultural Implements Manufacturing Company (SAIMCO) and, input and output traders and marketers. NGOs 
played a facilitating role. SAIMCO mainly manufactured and supplied farm implements such as hoes and ox ploughs. The value chain mapping results herein are presented based on existing and potential value chain components including: input supply, production, processing and marketing. The actors' costs and benefits results are based on two marketing channels; namely the city and other marketing channels.

\section{Citrus value chain characteristics}

Input supply. Value chain actors of the input supply category comprised of Government, private sector, individual farmers and farmer groups (Fig. 1). Through NaCRRI, NAL and NaSAARI, Government maintained and managed citrus mother gardens used for multiplication of planting materials. The Government's major seed multiplication site was in Kiige Citrus Scheme, located in Kamuli District. Besides, about $1 \%$ of individual farmers and $5 \%$ of farmer groups multiplied seedlings, in approximately 0.4 hectare gardens, using grafting and budding technologies. Overall, seedling producers found budding technology more economical and easier to use so, majority ( $89 \%)$ of the households established orchards using budded plantlets.

Seedlings were distributed by NAADS, NGOs (World Vision and Soroti Catholic Diocese Integrated Development Organisation (SOCADIDO), individual farmers and farmer groups. The seedlings supply consisted of both formal and informal systems. The formal system involved securing accredited material for seed multiplication from NaCRRI or its, affiliates, including National Agricultural Research Laboratories and National Semi Arid Agricultural Research Institute. These materials were used by individuals or farmer groups to multiply seedlings, with the supervision of MAAIF and/or NARO; and subsequently distributed to farmers either by NAADS, NGOs or farmer groups. The informal system, on the other hand, involved individual farmers or farmer groups sourcing seed multiplication materials from anywhere, multiplying and distributing them to farmers through onfarm sales or open market place sales. The main problem affecting production planning at seedling supply stage was variety uncertainty, which was attributed to limited/ lack of materials traceability. Nevertheless, MAAIF is cognisant of the existence of both formal and informal seed supply systems, and is encouraging the development of a viable commercial seed sector through public-private partnerships.

Soroti Agricultural Implements Manufacturing Company (SAIMCO), which is a private sector actor supplied farm implements such as, ox ploughs and hoes. Relatively large agro-chemical farms such as Industrial and Agricultural Chemicals Ltd. and Bukoola Chemicals Industries Ltd. supplied pesticides and fertilisers to individual input traders, who in turn retailed the products either in shops or village open markets. The input supply system consisted of both formal and informal subsystems; besides there was lack of distribution networks. A similar observation was made by Wandulu (2004); while assessing input distribution in Uganda. Consequently, farmers faced challenges of ascertaining the quality of inputs purchased. For instance, farmers could not distinguish the varieties of oranges grown until they started fruiting. This is a common challenge in developing countries, though elsewhere, it has been addressed through innovation platforms because they facilitate and strengthen interactions and collaboration between networks of stakeholders (Schut et al., 2015).

Production. Smallholders constituted over $95 \%$ of producers of citrus in the study area. Majority (92\%) of citrus farming households were male headed. On average, land allocated to citrus farming ranged from 0.04 to 2.4 hectares per household; with an overall average of 0.4 ha. In general, oranges dominated over other components within the citrus sub-sector. Across districts (Soroti, Kumi and Kaberemaido), there was no significant 
difference in land allocation to orange fruit farming. Generally, land on which citrus was grown belonged to the households, thus facilitating strategic planning, which is essential for planting and removal decisions.

On disaggregation of producers based on number of orange trees raised, 56.8, 22.6 and $20.6 \%$ of the households had less than 100 , 100 to 200 and more trees, respectively. Across districts, Kumi constituted the highest percentage (59.7 and $27.1 \%$ ) of producers with less than 100 and 100 to 200 trees, respectively. Soroti District on the other hand, had the highest percentage $(32.2 \%)$ of households managing more than 200 trees. This could be because the latter was the pioneer district for NAADs citrus promotion and development activities (Nandawula, 2011).

Common varieties of oranges grown included Sweet Valencia, Washington Navel, Hamlin and the local orange. Orchard management practices were basic, as most producers grew trees under natural conditions, with limited use of fertilisers and pesticides. Among the producers that used fertilisers, 58.6 and $5.2 \%$ used organic and inorganic fertilisers, respectively; while $21.5 \%$ used a combination of organic and inorganic fertilisers, but on irregular basis. On the otherhand, over $90 \%$ of the respondents used pesticides and fungicides to control pest and disease attack but applied indiscriminately and on irregular basis.

Orchard weeding on average was done 3 times a year by slashing, hoeing and/or ploughing using ox-ploughs. Hoeing, ploughing and slashing techniques were exclusively used by $19.4,8.9$ and $4.7 \%$ of the households, respectively; while a combination of hoeing and ploughing was used by $66.8 \%$ of the households. Ploughing under trees often resulted in damage to roots; implying that the weed management technologies could have affected output levels.

Most $(96.5 \%)$ of the labour used for orchard management was family sourced; implying that citrus enterprise in Kyoga Plains Agricultural Zone is mainly a self-employment undertaking. Generally, production was rain dependent, yet the study area experiences two dry seasons. Consequently, the crop suffered from insufficient soil moisture, especially during the dry period, December to March, thus affecting yields and quality of fruits.

Harvesting and postharvest management. Harvesting of orange fruits was done throughout the year, with a major peak period running from September to December. Once picked from the tree, the fruits were packed in polythene bags for pricing and transportation to various destinations for distribution. Some of the harvested fruits were sold immediately after harvest; while the rest were stored in mud huts with grass-thatched roofs, with or without grass on the floor. Some losses arising from rotting were reported where fruits were kept in farm storage for a number of days. This specifically happened in situations where traders gave the impression that they preferred fruits that had spent some time in farm storage because the peel would develop some resistance to breakage and, thus minimise damage during transportation.

Processing. The main citrus processing firms in the country included Britania Allied Industries and Jakana Foods Limited, both located in Kampala City. Much as these firms processed citrus into fruit juices, they did not use citrus fruits from Kyoga Plains Agricultural Zone as their raw material. Britania Allied Industries imported pulp from South Africa, apparently because local oranges could not produce the colour and taste of products required by their customers. Jakana Foods Limited, on the other hand, had limited processing capacity and it sourced oranges from Luwero and Sembabule Districts. This suggests that there was limited citrus processing taking place in the study area, and Uganda as a whole. Nevertheless, through bilateral cooperation between the Government of Uganda and the Korean Government, in partnership with Teso Tropical Fruit Growers Cooperative Union (TETFGCU), a fruit 
processing factory was being constructed in Soroti District, targeting processing citrus into juice (UDC, 2015b).

Marketing. At market level, value chain actors comprised of farmers, wholesalers, retailers, brokers/commission agents and transporters, who dealt in fresh fruits at domestic and regional markets. The purchase and sale transactions were conducted informally, as orange fruits moved from producers to consumers through different channels. At household level, farmers that produced relatively large quantities of orange fruits, traded directly with wholesalers; while those that produced small quantities bulked them at agreed upon assembly points of sale to wholesalers. In some instances, farmers sold fresh fruits to final consumers in urban and village markets, roadsides and by hawking both in the urban and village settings.

Wholesalers commonly worked closely with brokers and transporters to ensure that the commodity was assembled from the rural areas, and was appropriately transported to respective destinations. Brokers acted as intermediaries between producers and traders, and traders and transporters at both farm and market levels. Transporters often used trucks/ lorries and bus boots to move oranges from production to distribution points.

The transport cost, on average, was about 55 Uganda shillings (US\$ 0.02) per bag of 100 $\mathrm{kg}$ per kilometer. However, transport costs varied depending on quantity transported, means of transport and distance covered. For instance, transporting a metric tonne of citrus from Soroti Town to Kampala whose driving distance is approximately $347 \mathrm{~km}$, attracted a cost of 80,000 Uganda shillings (US\$ 33.9) by bus boot and from 100,000 to 150,000 Uganda shillings ((US\$ 42.4 - 63.6) by truck or lorry. Brokerage fees at market level ranged from 2,000 to 5,000 Uganda shillings (US\$ 0.8 - 2.1) per bag.

The brokerage fees were paid by the actor who requested for the service. Where parties to the transaction had established strong business relationships, brokerage services were not required, instead mobile phones were used to arrange deals.

Wholesalers sold oranges at prices ranging from 30,000 to 70,000 Uganda shillings (US\$ 12.7 - 29.7) and 40,000 to 100,000 Uganda shillings (US\$ 29.7 - 42.4) per bag in towns and the city, respectively. Teso Tropical Fruit Growers Association (TTFGA) was the only institution that attempted to play the role of linking farmers to markets through advocacy and provision of market information, but respondents indicated that they were yet to realise its contribution.

At retail level, fresh fruits were sold in the open in the city, town and village markets, road-sides, kiosks and at farm gates. The price ranged between 50 and 1,000 Uganda shillings (US\$ 0.01 and 0.3) per fruit depending on size and place of sale. Small sized fruits at retail level were sold in heaps; while large ones were sold per fruit. The heaps of small size oranges which attained an average 10 fruits, were sold at 1,000, 2,000 and 5,000 Uganda shillings (US\$ 0.4, 0.8 and 2.1) depending on quality and quantity. The large sized ones were sold either at Uganda shillings 500 or 1,000 (US\$ 0.2 or 0.4 ) per fruit. The major Kampala city markets in which oranges from Kumi, Soroti and Kaberemaido were sold include Kalerwe, Nakasero, Nakawa and St. Balikudembe; while the non-city ones include Iganga, Jinja, Mbale, Busia, Malaba and various large local markets.

Rural traders preferred Sweet Valencia to other varieties; while City traders preferred Washington naval because of its large size. Quality attributes considered by orange fruit buyers included colour, maturity level, size, taste and texture. Independent attribute rating results showed that taste, size and colour were the most important attributes as indicated by $64.0,46.6$ and $16.3 \%$ of the respondents, respectively. FITU (2007) reported similar results in an assessment of the fruits subsector in Uganda. 
Independent rating of farmers' trader preferences showed that majority prefered dealing with large traders (wholesale buyers) mainly because they paid cash, made bulk purchases and guaranteed market for their produce. Only 3 and $2 \%$ of the respondent households indicated preference for large traders because they offered loans and provided market information, respectively. Although marketing activities seemed well coordinated, it was observed that traders seldom made unplanned show ups at farmers' fields. At times, traders over delayed collection of fruits, probably as a strategic bargaining tool for compelling farmers to offer lower prices given that the crop was highly perishable. So, in spite of their preferences, farmers unanimously indicated that they did not trust traders. This presents a problem because mutual trust is critical for effective provision of information, financial support services, and strategic value chain coordination (Dunn, 2012).

Research and extension. Limited progress has been made in terms of scientific research on citrus particularly orange varieties and their suitability for productivity enhancement and processing. The National Crops Resources Research Institute (NaCRRI), which is mandated to handle scientific research on horticultural crops, still lacks ongoing scientific research work on citrus, and particularly oranges. The Institute, however, is involved in germplasm conservation, demonstrations and supply of plantlets to seedling producers and farmers, respectively.

Findings on access to extension service showed that farmers received advice from demonstrations provided at the NaSAARI and selected farmer/group nurseries and orchards. In addition, various NGOs such as SOCADIDO and World Vision, TTFGA, and Government institutions; namely NAADS and Local Government engaged in extension service provision. Overall, $73 \%$ of the respondents received extension advice mainly in demo sites and workshops, but with the focus on farm production. This highlights the need to refocus extension services to cover the entire citrus value chain.

Policy. Overall, agricultural development policy instruments, including Marketing and Agro-Processing Strategy (MAPS), Rural Development Strategy (RDS), National Agricultural Policy (NAP) and Development Strategy and Investment Plan (DSIP) provide the enabling environment for crop enterprises. MAPS brought about the zoning of agricultural production areas so as to integrate production, processing and marketing, thus the formation of Kyoga Plains Agricultural Zone. Through MAPS and RDS implementation, farmers received education and advisory services on the use of grafting and budding technologies for planting materials production and citrus orchards management. MAPS and RDS also facilitated formation of farmer institutions such as Teso Tropical Fruit Growers Association which transformed to Teso Tropical Fruit Growers Cooperative Union. Teso Tropical Fruit Growers Association (TTFGA) played the advocacy role with the aim of linking farmers to markets. However, it was observed that its benefits were yet to be realized by the citrus farmers. Teso Tropical Fruit Growers Cooperative Union in collaboration with the Government of Uganda and South Korea constructed a fruit processing factory in Soroti district targeting to process citrus into juice (UDC, 2016).

\section{Performance of value chain actors}

Input suppliers. Results showed that multiplying seedlings on 0.41 hectares of land at a spacing of 3 feet generated total variable costs amounting to $11,476,800$ Uganda shillings (US\$ 4,863.1) (Table 5). Labour constituted the highest proportion (71\%) of the variable costs, while agro-chemicals accounted for only $3.5 \%$ of the variable costs. This suggests that seed production is labour 
intensive and is largely done under basic farm management conditions. Seedling marketing, other farm supplies and plantlet costs constituted $12.4,12.7$ and $0.4 \%$ of the variable costs, respectively. Plantlet prices ranged from 1,500 - 3,000 Uganda shillings (US\$ 0.6 $-1.3)$ per unit. Generally, plantlets price varied depending on place of sale and persons involved in the transactions.

Using the average plantlets price of 2,000 Uganda shillings (US\$ 0.8) per unit, gross margin analysis results demonstrated that an input supplier generates a gross margin of 17,563,200 Uganda shillings (US\$ 7,442.0) per 0.41 hectares of plantlets per year. Generally, limited financing was highlighted as the main challenge to input supply. This was because it was inevitable to hire labour, especially during peak periods of the farming activity implying that it attracted relatively high costs.

Producers. At production level, findings of investment requirements analysis showed that essential orchard establishment costs arose from cost items such as hoes, plantlets and labour for land preparation, planting and seedlings irrigation. The farm implements costs ranged from 4,500 to 9,000 Uganda shillings (US\$ 1.9 - 3.8) (Table 1). Most basic farm tools (hand hoes, pangas, and watering cans) were owned by the households and used for general purposes.

Generally, most $(96 \%)$ of the producers employed family labour for farm production. When deemed necessary, especially during peak periods, additional labour (4\%) was hired to work at wage rates ranging between 1,000 and 2000 Uganda shillings (US\$ $0.4-0.8$ ) per 0.13 hectares of land (ekatala). It was observed that farmers who had some orchard establishment knowledge provided a tree spacing of $6 \mathrm{~m} \times 6 \mathrm{~m}$; while those who did not have any spacing knowledge intuitively spaced the trees. On average, 125 trees were planted per 0.41 hectares. The minimum level of investment required for a household to establish one acre of orange fruits orchard is 425,000 Uganda shillings (US\$ 180.1).

Overall, farm management costs and benefits to producers were determined based on basic and improved levels of orchard management practices. Basic level management practices entailed use of organic fertiliser (manure), minimal use of pesticides and light pruning; while improved management practices involved relatively more use of agrochemicals, higher weeding frequency, light and heavy pruning and organic and inorganic fertiliser use.

Findings showed that per 0.41 hectares yield of oranges under basic farm management conditions was 1.5 bags per tree per year, which is within the range of $1-3$ bags per tree per year as reported by PMA (2009). With each bag weighing on average 80 kilogrammes, an orchard with 125 fruiting trees per 0.41 hectares yields total output of $15,000 \mathrm{~kg}$ per year. Farm gate prices ranged from 100 to 750 Uganda shillings (US\$ $0.04-0.3$ ) per kilogramme. The average price was 420.8 shillings (US\$ 0.2) per $\mathrm{kg}$ of oranges.

TABLE 1. Price details of farm implements

\begin{tabular}{|c|c|c|c|c|}
\hline \multirow[t]{2}{*}{ Item } & \multicolumn{2}{|c|}{ Cost in Uganda Shillings } & \multicolumn{2}{|c|}{ Cost in United States dollars } \\
\hline & Minimum & Maximum & Minimum & Maximum \\
\hline Hand hoe & 4,500 & 9,000 & 1.9 & 3.8 \\
\hline Panga & 9,000 & 12,000 & 3.8 & 5.1 \\
\hline Watering can & 10,000 & 12,000 & 4.2 & 5.1 \\
\hline Ox ploughs & 100,000 & 180,000 & 42.4 & 76.3 \\
\hline
\end{tabular}


Therefore, under basic farm management conditions, farmers were able to earn a net margin of 44,610 Uganda shillings (US\$18.9) per tree per annum (Table 6). This is equivalent to 4,550,250 Uganda shillings (US\$ 1,928.1) per 0.41 hectares per annum. Farmers employing improved farm management practices earned a net margin of 85,884 Uganda shillings (US\$36.4) per tree per annum and 7,491,240 Uganda shillings (US\$ 3,174.3) per 0.41 hectares per annum.

When benefits under basic and improved farm management practices are compared, per unit net margin under basic farm management is higher than that obtained under improved management. This could be attributed to fairly abundant labour with natural soil fertility and organic manure application (PMA, 2009; UDC, 2012). Likewise, net margin percentages under basic and improved farm management practices were 85 and $79 \%$, implying that higher profitability levels were registered when households used basic farm management practices as opposed to those using improved farm management practices. However, crop enterprises run under basic farm management practices are unsustainable and cannot help farmers to strategically align themselves to avert effects of climate change and adapt to globalising/globalised marketing conditions because they may overtime succumb to shocks leading to great losses (Kilelu et al., 2017).
Gross marketing margins. Various marketing channels were used to distribute oranges from the points of production to final consumers. For instance, oranges were moved from farm to local market, farm to roadsides, local market to town markets and farm to regional markets. The actors in orange fruit marketing channels included individual farmers, assemblers, wholesalers and retailers. For the purpose of this study, only two key channels were analysed because of consumer, price and costs similarities. The city channel attracted relatively high prices and a broader customer base; while the other channel had low prices, associated costs and customer base. This could be because the other channel mainly served areas that were relatively near the source and mainly consisted of the low and middle income customer base. Therefore, based on the two marketing channels, costs and benefits of actors were assessed from farms till produce reached the consumer (Tables 2 and 3). Distribution channel 1 involved movement of orange fruits from farm through assemblers, city wholesalers, city retailers to consumers (Table 2). In the city channel, the highest added costs were incurred by wholesalers $(43 \%)$, followed by farmers (31\%). This could be attributed to costly investment on transportation and orchard management, respectively. In spite of the high costs, wholesalers and farmers obtained prices

TABLE 2. City channel actors' costs and benefit shares in the citrus value chain in Uganda

\begin{tabular}{|c|c|c|c|c|c|c|c|}
\hline \multirow[t]{2}{*}{ Chain actor } & \multicolumn{3}{|c|}{ Costs $\left(\mathrm{US} \$ \mathrm{~kg}^{-1}\right)$} & \multicolumn{3}{|c|}{ Revenues (US\$ kg-1) } & \multirow{2}{*}{$\begin{array}{c}\text { Retail } \\
\text { price }(\%)\end{array}$} \\
\hline & Unit cost & $\begin{array}{l}\text { Added } \\
\text { unit cost }\end{array}$ & $\begin{array}{l}\text { Added } \\
\text { cost }(\%)\end{array}$ & Unit price & $\begin{array}{c}\text { Unit net } \\
\text { MM }\end{array}$ & $\begin{array}{l}\text { Total net } \\
\text { MM (\%) }\end{array}$ & \\
\hline Farmers & 0.04 & 0.04 & 31.25 & 0.18 & 0.14 & 41.15 & 38.27 \\
\hline Assemblers & 0.18 & 0.01 & 5.94 & 0.20 & 0.01 & 4.49 & 4.91 \\
\hline Wholesalers & 0.20 & 0.06 & 43.13 & 0.38 & 0.12 & 36.03 & 38.09 \\
\hline Retailers & 0.38 & 0.03 & 19.69 & 0.47 & 0.06 & 18.33 & 18.73 \\
\hline Total & & 0.14 & & & 0.33 & 100 & 100 \\
\hline
\end{tabular}


TABLE 3. Other channel actors' costs and benefit shares of the citrus value chain in Uganda

\begin{tabular}{|c|c|c|c|c|c|c|c|}
\hline \multirow[t]{2}{*}{ Chain actor } & \multicolumn{3}{|c|}{ Costs $\left(\mathrm{US} \$ \mathrm{~kg}^{-1}\right)$} & \multicolumn{3}{|c|}{ Revenues (US\$ kg-1) } & \multirow{2}{*}{$\begin{array}{l}\text { Retail } \\
\text { price }(\%)\end{array}$} \\
\hline & Unit cost & $\begin{array}{l}\text { Added } \\
\text { unit cost }\end{array}$ & $\begin{array}{l}\text { Added } \\
\text { cost }(\%)\end{array}$ & Unit price & $\begin{array}{c}\text { Unit net } \\
\text { MM }\end{array}$ & $\begin{array}{l}\text { Total net } \\
\text { MM (\%) }\end{array}$ & \\
\hline Farmers & 0.04 & 0.04 & 42.02 & 0.18 & 0.14 & 62.7 & 56.13 \\
\hline Assemblers & 0.18 & 0.01 & 7.98 & 0.20 & 0.01 & 6.8 & 7.20 \\
\hline Wholesalers & 0.20 & 0.04 & 36.97 & 0.28 & 0.04 & 19.5 & 25.07 \\
\hline Retailers & 0.28 & 0.01 & 13.03 & 0.32 & 0.02 & 10.9 & 11.66 \\
\hline Total & & 0.10 & 100.0 & & 0.22 & 100.0 & 100.0 \\
\hline
\end{tabular}

which represented the highest proportion of the retail price 38.1 and $38.3 \%$, respectively.

This could be because they only invested in communication for establishing linkages between actors, but the rest of the costs were directly borne by the initiator of the trading relationship. The wholesalers obtained higher margins than retailers, but their profit proportions were within a fair range of about 20\% (Kongai et al., 2017).

Other marketing channel involved movement of orange fruits from farm to local major markets, town centres distributed through wholesalers and retailers. Other channels cost and benefit analysis results showed that farmers incurred the highest added costs (42\%) and obtained the highest retail price share $(56.1 \%)$ compared to rural assemblers, wholesalers and retailers (Table $3)$. According to Marti (2007) this can happen where farmers have high bargaining power, which is not the case in the area of study. However, in spite of the high added costs incurred by farmers, it is apparent that production of oranges was done with greater efficiency probably because basic farm management practices were employed. The efficiency benefits could have arisen from employment of family labour, which in some instances was valued at zero cost especially when there is no alternative employment.

The gross margin shares (GMS) per actor were computed based on retail price and later deflated using CPI to remove location and time effects. Results showed that farmers and wholesalers seemed to capture a higher proportion of the GMS; 43.6 and $43.4 \%$, respectively (Table 4). Generally, retail price based gross margin shares were lower than the standardised GMS.

Value chain linkages. Farmers generally expressed interest in increasing their market and profitability by establishing closer strategic relationships among themselves and with their customers. However, managing cooperation modalities was a challenge to $75 \%$ of the respondents. Generally, respondents indicated that they previously tried to cooperate in setting the price of their produce, and to market it collectively, but they were often let down by their colleagues who sold their produce at lower price due to critical household cash demands.

It was also noted that farmers generally did not trust traders. They viewed the latter as exploiters, although they preferred dealing with large traders because of cash payment, bulk purchases and guaranteeing market for produce. The lack of trust and cooperation among citrus value chain actors deprived them of synergy and learning that would have arisen from working as a strategic unit, to enable development of new skills and capabilities, which lead to better income generating opportunities (Kongai, 2017). 
TABLE 4. Standardised gross margin shares from production to consumption in the citrus value chain in Uganda

\begin{tabular}{|c|c|c|c|c|c|c|c|c|}
\hline \multirow[t]{3}{*}{ Type of GM } & \multicolumn{4}{|c|}{ Standardised gross margin shares } & \multicolumn{4}{|c|}{ Un-standardised gross margin shares } \\
\hline & \multicolumn{2}{|c|}{ Channel 1} & \multicolumn{2}{|c|}{ Channel 2} & \multicolumn{2}{|c|}{ Channel 1} & \multicolumn{2}{|c|}{ Channe 2} \\
\hline & $\begin{array}{c}\text { Price } \\
\left(\mathrm{US} \$ \mathrm{~kg}^{-1}\right)\end{array}$ & $\begin{array}{l}\text { GM } \\
(\%)\end{array}$ & $\begin{array}{l}\text { Price } \\
\left(\mathrm{US} \$ \mathrm{~kg}^{-1}\right)\end{array}$ & $\begin{array}{l}\mathrm{GM} \\
(\%)\end{array}$ & $\begin{array}{c}\text { Price } \\
\left(\mathrm{US} \$ \mathrm{~kg}^{-1}\right)\end{array}$ & $\begin{array}{l}\text { GM } \\
(\%)\end{array}$ & $\begin{array}{c}\text { Price } \\
\left(\mathrm{US} \$ \mathrm{~kg}^{-1}\right)\end{array}$ & $\begin{array}{r}\text { GM } \\
(\%)\end{array}$ \\
\hline Farmer participation & 0.18 & 42.27 & 0.18 & 59.89 & 0.18 & 38.27 & 0.18 & 56.13 \\
\hline Rural Assembler GM & 0.20 & 5.59 & 0.20 & 7.68 & 0.20 & 4.91 & 0.20 & 7.20 \\
\hline Wholesaler & 0.38 & 43.37 & 0.28 & 26.74 & 0.38 & 38.09 & 0.28 & 25.07 \\
\hline Retailer (CPI) & 0.41 & 7.45 & 0.30 & 5.69 & 0.47 & 18.73 & 0.32 & 11.60 \\
\hline GMM & 0.23 & 56.42 & 0.12 & 40.11 & 0.29 & 61.73 & 0.14 & 43.87 \\
\hline
\end{tabular}

TABLE 5. Costs and revenue for production and supply of plantlets on one acre

\begin{tabular}{|c|c|c|c|c|c|}
\hline Item/activity & $\begin{array}{l}\text { Units of } \\
\text { measure }\end{array}$ & Quantity & $\begin{array}{l}\text { Unit price } \\
\text { (US\$) }\end{array}$ & $\begin{array}{c}\text { Total } \\
\text { value (US\$) }\end{array}$ & $\begin{array}{c}\text { Total } \\
\text { value }(\%)\end{array}$ \\
\hline \multicolumn{6}{|l|}{ Labour costs } \\
\hline Land clearing & Hectares & 0.41 & 0.30 & 12.71 & 0.26 \\
\hline Cultivation/ploughing & Hectares & 0.41 & 0.40 & 21.19 & 0.44 \\
\hline Bed preparation & Beds & 60 & 1.00 & 50.85 & 1.05 \\
\hline Planting & & 60 & 0.50 & 25.42 & 0.52 \\
\hline Thinning (light) & & 60 & 0.50 & 25.42 & 0.52 \\
\hline \multirow[t]{2}{*}{ Watering (initial) } & Beds & $60 \times 30$ & 15.70 & 762.71 & 15.68 \\
\hline & Hectares & 0.41 & 9.40 & 457.63 & 9.41 \\
\hline Spraying (10 times) & Hectares & 0.41 & 0.40 & 21.19 & 0.44 \\
\hline Weeding ( 10 times) & Hectares & 0.41 & 6.10 & 296.61 & 6.10 \\
\hline Harvesting costs & & 14,520 & 12.40 & 601.69 & 12.37 \\
\hline \multicolumn{6}{|c|}{ Materials and other costs } \\
\hline Seed & Bags & 2 & 0.40 & 21.19 & 0.44 \\
\hline Bags/pots & Bags & 14,520 & 12.70 & 615.25 & 12.65 \\
\hline Grafting/budding & Plants & 14,520 & 19.20 & 933.90 & 19.20 \\
\hline Potting & & 14,520 & 5.10 & 246.10 & 5.06 \\
\hline Fertiliser & & 6 & 1.00 & 50.85 & 1.05 \\
\hline Pesticide & & 10 litres & 1.70 & 84.75 & 1.74 \\
\hline Fungicide & Litres & 4 litres & 0.70 & 33.90 & 0.70 \\
\hline Marketing costs & & 14,520 & 12.40 & 601.69 & 12.37 \\
\hline Total cost & & & & $4,863.05$ & 100.0 \\
\hline Yield for 0.41 ha & Hectares & 14,520 & & $12,305.08$ & \\
\hline Net revenue & & & & $7,442.03$ & \\
\hline Percent net revenue & & & & $60 \%$ & \\
\hline
\end{tabular}

Exchange rate $=$ US $\$ 1=2,360$ Uganda shillings 
TABLE 6. Farm level costs and benefits for oranges produced and sold at farm-gate

\begin{tabular}{|c|c|c|c|c|c|c|c|c|}
\hline \multirow{2}{*}{$\begin{array}{l}\text { Item/activity } \\
\text { Variable cost }\end{array}$} & \multirow[t]{2}{*}{ Details } & \multirow[t]{2}{*}{ Units } & \multicolumn{3}{|c|}{ Basic practice } & \multicolumn{3}{|c|}{ Improved practice } \\
\hline & & & Quantity & $\begin{array}{l}\text { Unit price } \\
\text { (US\$) }\end{array}$ & $\begin{array}{l}\text { Total value } \\
\text { (US\$) }\end{array}$ & Quantity & $\begin{array}{l}\text { Unit price } \\
\text { (US\$) }\end{array}$ & $\begin{array}{l}\text { Total value } \\
\text { (US\$) }\end{array}$ \\
\hline \multirow[t]{2}{*}{ Weed control } & Cultivation (3) & Acres & 3 & 12.71 & 38.14 & 4 & 12.71 & 50.85 \\
\hline & Herbicide & Litres & & 0.00 & 0.00 & 6 & 8.47 & 50.85 \\
\hline \multirow[t]{2}{*}{ Pruning } & Light (x2) & Trees & 125 & 0.04 & 5.30 & 110 & 0.04 & 4.66 \\
\hline & Heavy (x2) & Trees & & 0.00 & 0.00 & 110 & 0.13 & 13.98 \\
\hline Fungicide & & Litres & 6 & 6.36 & 38.14 & 8 & 8.47 & 67.80 \\
\hline Pesticide & & Litres & 6 & 8.47 & 50.85 & 8 & 10.59 & 84.75 \\
\hline \multirow[t]{2}{*}{ Fertiliser } & Manure & & 125 & 0.21 & 26.48 & 110 & 0.21 & 23.31 \\
\hline & Inorganic & $\mathrm{Kg}$ & & 0.00 & 0.00 & 80 & 0.64 & 50.85 \\
\hline Spraying & & Acres & $1 \times 6$ & 2.12 & 12.71 & 11 & 2.12 & 23.31 \\
\hline Harvesting & & Bags & 187.5 & 0.85 & 158.90 & 330 & 0.85 & 279.66 \\
\hline Farm storage & & Huts & & & 42.37 & & 0.00 & 84.75 \\
\hline TVC & & & & & 346.40 & & 0.00 & 828.81 \\
\hline AVC (TVC/kg) & & & & & 0.02 & & 0.00 & 0.03 \\
\hline Yield & & $\mathrm{Kg}$ & 15,000 & 0.18 & 2675.85 & 26,400 & 0.18 & 4709.49 \\
\hline Loss $(15 \%)$ & & $\mathrm{Kg}$ & 2,250 & 0.18 & 401.38 & 3,960 & 0.18 & 706.42 \\
\hline Total revenue & & $\mathrm{Kg}$ & 12,750 & 0.18 & 2274.47 & 22,440 & 0.18 & 4003.07 \\
\hline GP/acre & & & & & 1928.07 & & & 3174.25 \\
\hline Gross profit/tree & & & & & 18.90 & & & 36.39 \\
\hline Profit (\%) & & & & & $85 \%$ & & & 79 \\
\hline
\end{tabular}

$\mathrm{TVC}=$ Total variable costs, $\mathrm{AVC}=$ Average variable costs, $\mathrm{GP}=$ Gross profit $/$ margin 


\section{CONCLUSION}

The analysis of the citrus value chain of Teso Sub-region of Uganda has revealed that oranges pre-dominated the components of this enterprise. The most limiting factors to the citrus value chain performance include limited traceability of distribution of planting materials, use of unimproved production practices, poor post-harvest management and limited value addition to fruit harvests. The over-arching weaknesses within the value chain were linked with sub-optimal production planning and unrealable marketing systems. In order to bolster market competitiveness of the citrus sub-sector, it is imperative that policies to ensure distribution of planting material with clear traceability and to enhance value addition should be implemented.

\section{ACKNOWLEDGEMENT}

We are grateful to the International Development Research Centre (IDRC) and Carnegie Foundation for providing the financial support for this research work. University of Malawi, Lilongwe University of Agriculture and Technology and, the Regional Universities Forum for Capacity Building in Agriculture (RUFORUM) provided technical support.

\section{REFERENCES}

Collins, R. 2011. Translating consumer insights into sustainable competitive advantage. University of Queensland; Workshop held in Mississauga, Ontario, Canada.

Dunn, E. 2012. Facilitating systemic change in value chains: Lessons learned for strengthening country systems. Available at http://usaidlearninglab.org Accessed on 11 June 2016)

FITU 2007. Study for fruits sub-sector (pineapples, passion fruits, mangoes. FIT Uganda Ltd. and Ssemwanga Consulting Ltd., Kampala, Uganda.
Johnston, L.G. and Sabin, K. 2010. Sampling hard-to-reach populations with respondent driven sampling. Methodological Innovations Online 5(2): 38-48. Available at www.methodologicalinnovations. org. uk/wp-contents/uploads/2013/5 Accessed on 15 June 2014).

Kongai, H., Mangisoni ,J., Elepu, G., Chilembwe, E., Kwapata, M.B. and Makoka, D. 2011. Citrus value chain in Eastern Uganda. African Crop Science Conference Proceedings 10:19-21.

Kongai, H. 2017. Analysis of citrus value chain, market access and supply response in Kyoga plains agricultural zone in Uganda. $\mathrm{PhD}$ thesis, Bunda College of Agriculture, University of Malawi, Lilongwe, Malawi, 220pp.

Marti, M.A.M. 2007. The gap between producer prices and the prices paid by the consumer. Policy Department Sctructural and Cohesion Policies. Agra CEAS Consulting. Available at http://www.ceasc. com/Images/Content/2326/Report.pdf Accessed on 26 June 2017.

Nandawula, P. 2011. The contribution of the National Agricultural Advisory Services (NAADS) Programme to Women's Empowerment: A case of Lwankoni subcounty in Uganda. MSc. thesis, University of Bergen, Norway. 115pp.

Plan for Modernisation of Agriculture (PMA). 2009. Citrus Market Study Report for Teso Sub-Region. Ministry of Agricultural Animal Industry and Fisheries, Entebbe, Uganda.

Porter, M.E. 1998. The competitive advantage: Creating and sustaining superior performance. The Free Press, New York, USA.

Schut, M., Cadilhon, J.J., Masiko, M. and Dror, J. 2015. The state of innovation platforms in agricultural research for development. In: Innovation Platforms for Agricultural Development. Evaluating the mature innovations platforms landscape. 190pp. 
Tchale, H. and Keyser, J. 2010. Quantitative value chain analysis : An application to Malawi. Policy Research Working Paper No. WPS 5242. World Bank. (C) World Bank. Available at https://openknowledge. worldbank.org/handle/10986/3730 License: CC BY 3.0 IGO.” Accessed on 20 October 2010.

Uganda Bureau of Statistics (UBOS), 2009. Consumer Price Index, UBOS, Kampala, Uganda.

Uganda Bureau of Statistics 2016. The National population and housing census 2014. Main Report. Kampala, Uganda.

Uganda Development Cooperation (UDC) 2012. Teso citrus feasibility study, Deloitte (Uganda) Ltd, Kampala, Uganda.
Uganda Development Cooperation (UDC), 2015a. Improving production and marketing of high quality citrus and mango fruits in Teso Sub-region. Korea International Cooperation Agency (KOICA), Kampala, Uganda.

Uganda Development Cooperation (UDC), 2015b. Soroti fruit factory Project. Available at www.udc.go.ug/index.php/ projects. Accessed on 19 May 2017.

Uganda Investment Authority (UIA). 2009. Investing in Uganda: Investment potentials in citrus fruit farming, Kampala, Uganda.

Wandulu, J.A. 2004. Facilitating agricultural input distribution in Uganda: Experiences based activities conducted by AT Uganda Ltd. Uganda Journal of Agricultural Sciences 9:758 - 765. 